\title{
Dietary powder and molecular imprinted polymer nanoencapsulated sodium propionate to enhance growth performance, digestive enzymes activity, antioxidant defense and mucosal immune response in African cichlid (Labidochromis lividus) fingerlings
}

mehrdad sarkheil ( $\square$ sarkheil@um.ac.ir)

ferdowsi university of mashhad

Omid Safari

Ferdowsi University of Mashhad

Davood Kordestani

Amirkabir University of Technology

Research Article

Keywords: Organic salt, Molecular imprinted polymer, Nanoencapsulation, digestive enzyme, antioxidant enzyme, Mucosal immunity, African cichlid.

Posted Date: February 16th, 2022

DOI: https://doi.org/10.21203/rs.3.rs-1219759/v1

License: (9) This work is licensed under a Creative Commons Attribution 4.0 International License.

Read Full License 


\section{Abstract}

This study was conducted to examine the effects of powder sodium propionate (P-SP) and SP loaded molecular imprinted polymer (MIP) nanoparticles (MIP-SP NPs) on growth, skin mucosal immune parameters and digestive and liver enzymes activities of African cichlid (Labidochromis lividus) fingerlings. The synthetized MIP-SP particles were characterized via FE-SEM/EDS, TEM, FTIR and ICPOES techniques. Fish with an average weight of $500 \pm 2 \mathrm{mg}$ were stocked into 12 experimental units and fed with experimental diets prepared by supplementation of basal diet (control) with MIP NPs, P-SP ( $5 \mathrm{~g}$ SP $\mathrm{Kg}^{-1}$ of dry diet) and MIP-SP NPs for 8 weeks. The findings demonstrated that growth performance parameters improved in the MIP-SP NPs followed by the P-SP dietary group compared to the control groups $(P<0.05)$. The activity of digestive enzymes of lipase, trypsin, protease and alkaline phosphatase was higher in the fish fed with SP-supplemented diets than the controls $(P<0.05)$. The highest activity of protease and lipase enzymes was observed in the MIP-SP NPs dietary group $(P<0.05)$. The alanine aminotransferase (ALT) and aspartate aminotransferase (AST) levels of liver tissue decreased in the SP dietary groups, while the catalase (CAT), superoxide dismutase (SOD) and alkaline phosphatase (ALP) levels increased in comparison to the control groups $(P<0.05)$. The highest SOD and ALP levels were observed in the fish fed with the MIP-SP NPs-supplemented diet $(P<0.05)$. The skin mucosal immune indices including alternative haemolytic complement activity (ACH50), lysozyme and total immunoglobulin (Ig) levels increased in the MIP-SP NPs and P-SP dietary groups in comparison to the controls $(P<0.05)$. The findings indicated that sodium propionate encapsulated in molecular imprinted polymer nanoparticles could enhance the efficiency of dietary SP in African cichlid fish.

\section{Introduction}

Nowadays, one of main constraints to productivity of aquaculture industry is outbreak of various bacterial, fungal and viral diseases. Traditionally, antibiotics have been administrated as growth promoters and controlling disease in animal feeds (Liu et al., 2014; Wongsasak et al. 2014; He et al., 2017). However, their usage in aquaculture is restricted because of emergence of antibiotic resistant pathogenic strains (Cabello et al., 2013; Safari et al., 2016; Chow et al., 2017), various adverse effects on the environment (Rico et al., 2012; Romano et al., 2014) and the threat to human consumers through accumulation of antibiotic residues in aquatic animals (Defoirdt et al., 2009; Marshall and Levy, 2011). During the past decades, various immunostimulants (Sajeevan et al., 2009; Safari and Sarkheil, 2018), probiotics (Camara-Ruiz et al., 2020; Wuertz et al., 2021) and prebiotics (Zhou et al., 2007; Safari and Paolucci, 2018) have been identified as environment friendly alternatives for antibiotics. Recently, the effects of dietary organic acids and their salts on growth performance, enhancement of immune status and disease resistance have been examined in various aquaculture species (Hoseinifar et al., 2016; Safari et al., 2017; He et al., 2017).

Organic acids and their salts composed of short-chain fatty acids (C1-C7) and carboxylic acids with one or more carboxyl group $(-\mathrm{COOH})$ in their structure are known as acidifier and often used in livestock feed for controlling disease (Defoirdt et al., 2009; $\mathrm{Ng}$ and Koh, 2016). It is believed that organic acids act their 
antibacterial effect through altering $\mathrm{pH}$ of bacterial cells thereby inhibiting the growth of bacteria and thus reducing pathogenic bacteria within the gastrointestinal tract of the host animal (Booth and Stratford, 2003; Baruah et al., 2008). Propionic, lactic, formic and formic acids and their salts are the most common organic acids examined in aquaculture (Hoseinifar, et al., 2016; $\mathrm{Ng} \& \mathrm{Koh}, 2016)$. There are reports that organic acids and their salts effectively enhance the growth, nutrient utilization and health status of aquatic animals (Agouz et al., 2015; Safari et al., 2016; Chow et al., 2017) probably due to a significant decrease in pH of gut and upper intestinal tract (Baruah et al., 2005; Abu Elala and Ragaa, 2015), increase in the digestive enzyme activities (Su et al., 2014; Castillo et al., 2014), stimulating the growth of intestinal epithelial cells (Topping and Clifton, 2001; Gao et al, 2011), improvement in the digestibility of major nutrients (Morken et al., 2011) and altering the gut microbial community (Silva et al. 2016). Van der Wielen (2002) reported that butyrate is less ideal as a feed additive for animals because of its quick absorption in the upper digestive tract. It has been shown that the efficiency of butyric acid can be increased when administrated in form of encapsulation due to slow release and effectively delivery of the butyric acid throughout of the gastro-intestinal tract (Chow et al., 2017). Leaching of organic acids and their salts from feed into water body is considered as a fundamental challenge in their administration in aquafeeds ( $\mathrm{Ng}$ and $\mathrm{Koh}, 2016)$. Encapsulation or coating of organic acids is beneficial approach to prevent leaching.

Drug delivery is a useful approach for slow and controlled release of pharmaceutical compounds to obtain the maximum therapeutic effects in humans or animals (Zaidi, 2016). Micro and nanoencapsulation technologies possess properties of entrapment, protection and controlled release of active ingredients and thus improving its bioavailability (Poncelet, 2006; Paramera et al., 2011). Biopolymers and synthetic ones are considered as very exciting and useful drug delivery devices in pharmaceutical industry (Lulinski, 2013; Zaidi, 2016). Molecularly imprinted polymers (MIP) as the drug dosage forms are synthetic materials that provide a great potential in drug delivery (Cunliffe et al., 2005; Piletsky and Turner, 2006). MIPs for drug delivery are usually synthetized by polymerization process in the presence of a template (target molecule), functional monomer and cross-linker (Jaiswal et al., 2015). MIPs exhibit outstanding advantages such as slow and controlled release of drug, efficient drug loading, stability and resistant to harsh conditions ( $\mathrm{pH}$, organic solvents, temperature, and pressure), biocompatibility and ease of preparation (Puoci et al., 2011; Gao et al., 2014; Asadi et al., 2016; Zaidi, 2016). Asadi et al. (2016) synthetized nano-structured molecularly imprinted polymer for controllable sustained release of olanzapine as an antipsychotic drug to the brain tissue of rat under external magnetic field. Zhu et al. (2017) also showed that vinblastine (VBL) loaded molecular imprinted nanoparticles (MIPNPs) had a sustained-release behavior and level of VBL loaded MIPNPs in tissues and serum of rats was higher than that of commercially available injection. To best of our knowledge, information on use of MIPs as drug or active ingredient carriers is limited in aquatic animals.

In the present study, a molecular imprinted polymer (MIP) was synthetized as a carrier for sodium propionate (SP) as a template and examined the potential effect of dietary SP loaded MIP nanoparticles versus powder SP on growth indices, activity of digestive and antioxidant enzymes as well as immune status of African cichlid (Labidochromis lividus) fingerlings. Cichlid fish are one of the most diverse and 
popular ornamental fish in the world. The African cichlid is one the most common species in aquarium fish farms and produce commercially for the ornamental fish market (Smith, 2000). The ornamental fish trade is growing rapidly worldwide (Raja et al., 2019). Therefore, enhancement of growth, health status and disease resistance of the fish is necessary for further development of the ornamental fish industry.

\section{Materials And Methods \\ 2.1 Chemicals}

Methacrylic acid, ethylene glycol dimethacrylate, potassium persulfate, acetone and ethanol were purchased from Merck Co. Sodium propionate $\left(\mathrm{C}_{3} \mathrm{H}_{5} \mathrm{NaO}_{2}\right)$ was also purchased from Sigma-Aldrich Co.

\subsection{Synthesis of molecular imprinted polymer-sodium propionate (MIP-SP) particles}

Firstly, $1 \mathrm{mM}$ methacrylic acid and $1 \mathrm{mM}$ sodium propionate (SP) were poured into $50 \mathrm{~mL}$ of water/ethanol solution (50:50 v/v) and mechanically stirred at room temperature for $1 \mathrm{~h}$. Afterwards, 4 $\mathrm{mM}$ ethylene glycol dimethacrylate and $0.1 \mathrm{M}$ potassium persulfate were added to solution, respectively. The mixture was stirred for $10 \mathrm{~min}$ and sonicated for $5 \mathrm{~min}$. Then, the reaction was purged using $\mathrm{N}_{2}$ for 10 min and a balloon filled with $\mathrm{N}_{2}$ was placed over the balloon reaction to deoxygenate the solution. The reaction balloon was placed in a bain-marie bath (water bath) at $60^{\circ} \mathrm{C}$ for $20 \mathrm{~h}$. In following, the reaction balloon cooled to room temperature. Sediment was collected from the bottom of balloon and washed several times with ethanol and acetone, respectively. The product (MIP-SP) was dried at room temperature. The synthetized MIP particles without loading SP were considered as control.

\subsection{Characterization of synthetized MIP-SP particles}

Field emission scanning electron microscopy (FE-SEM; MIRA3 TESCAN, Brno, Czech Republic) coupled with x-ray energy dispersive spectroscopy (EDS) was used to determine the shape, size and elemental composition of synthetized particles. Transmission electron microscopy (TEM; ZEISS LEO 912 AB) was also applied to determine the shape and size of particles. To measure the average diameter and size distribution of particles, the diameter of 310 individual particles on TEM images was measured using AxioVision digital image processing software (Release 4.8.2.0, Carl Zeiss Micro Imaging GmbH, Germany). The functional groups in MIP-SP particles were identified using fourier transform infrared (FTIR) spectroscopy (Bruker Alpha, Ettlingen, Germany) over range of $400-4000 \mathrm{~cm}^{-1}$.

The SP content of the synthetized MIP-SP nanoparticles was measured according to method described by Sarkheil et al. (2021) in triplicate. Briefly, $0.5 \mathrm{~g}$ of MIP-SP powder was poured into a $50 \mathrm{~mL}$ round bottom balloon containing $9 \mathrm{~mL}$ of $\mathrm{HCL}, 3 \mathrm{~mL}$ of $\mathrm{HNO}_{3}$ and $2 \mathrm{~mL}$ of $\mathrm{H}_{2} \mathrm{O}_{2}$. The powder sample was digested through maintaining the mixture at room temperature for $24 \mathrm{~h}$ and then, heating at $95^{\circ} \mathrm{C}$ for $2 \mathrm{~h}$. Afterwards, the digested sample was filtered using a Whatman filter paper $(0.45 \mu \mathrm{m})$ and diluted to $25 \mathrm{~mL}$ 
using double distilled water. Finally, the concentration of $\mathrm{Na}^{+}$ions in the solution was measured using inductively coupled plasma-optical emission spectrometry (ICP-OES).

\subsection{Preparation of experimental diets}

To prepare four experimental diets, a basal diet was supplemented with two forms of powder SP (P-SP) and MIP-SP nanoparticles (MIP-SP NPs) at the level of $5 \mathrm{~g} \mathrm{Kg}^{-1}$ of dry diet according to the SP inclusion level of diets for various fish species at different life stage (Hoseinifar et al., 2016; Wassef et al., 2019; Sarkheil et al., 2021). The basal diet without SP and supplemented with MIP nanoparticles (MIP NPs) was considered as control. The ingredients and proximate chemical analysis of the experimental diets are given in Table 1. To prepare the experimental diets, the basal diet was ground into powder form using a miller, boiling water was added, mixed well to convert into a uniform paste and then, different forms of SP was added. The dough was pelletized by using a meat grinder with a mesh diameter of $2 \mathrm{~mm}$ to match the size of commercial feeds. Afterwards, the pellets were dried at $30^{\circ} \mathrm{C}$ for $24 \mathrm{~h}$ and stored at $-20^{\circ} \mathrm{C}$ until use in the feeding trial. The $\mathrm{pH}$ of prepared diets was determined according to the procedure explained by Boland et al. (1981) by using a pH meter (Crison, Basic 20+, model).

\subsection{Proximate composition of diet}

The chemical composition of the experimental diets was analyzed in triplicate based on the standard methods (AOAC, 2005). Dry matter was measured by oven drying at $105^{\circ} \mathrm{C}$ for $24 \mathrm{~h}$; crude protein ( $\mathrm{Nx}$ 6.25) was determined by Kjeldahl system (Buchi Labortechnik AG, Flawil, Switzerland) after acid digestion; crude lipid was measured by Soxtec system HT 1043 (Foss Tecator, AB); ash content of diets was determined through placing the samples in a muffle furnace (Exciton Co., EX.1200-2 L, model) at $550^{\circ} \mathrm{C}$ for $12 \mathrm{~h}$. To analyze crude fiber of the experimental diets, $\mathrm{NaOH}$ (Merck Co.) and $\mathrm{H}_{2} \mathrm{SO}_{4}(\mathrm{Merck}$ Co.) solutions were used to digest the diet samples. Afterwards, the digested samples were placed in crucibles and dried at $120^{\circ} \mathrm{C}$ for $12 \mathrm{~h}$. The crucibles were transferred into a muffle furnace at $550^{\circ} \mathrm{C}$. Finally, the weight of crucibles was measured.

\subsection{Fish and experimental conditions}

The African cichlid (Labidochromis lividus) fingerling (average weight $0.5 \pm 0.002 \mathrm{~g}$ and average length $3.79 \pm 0.05 \mathrm{~cm}, \mathrm{n}=250$ ) were purchased from a local supplier of ornamental fish in Mashhad, Razavi Khorazan province. The fish were maintained in two $250 \mathrm{~L}$ fiberglass tanks filled with dechlorinated tap water under continuous aeration and 12:12 light: dark photoperiod for two weeks. During acclimation period, the fish were fed with the basal diet twice a day. In following, the fish were randomly divided in four groups in three replicates ( $n=18$ each replicate) and stocked in 12-glass aquarium (150 L) filled with $130 \mathrm{~L}$ of dechlorinated tap water. Each glass-aquarium was equipped with an air stone for continuous aeration by using a central air pump (Hailea ACO 318, India), an aquarium heater and a white fluorescent lamp for adjustment of water temperature to $25^{\circ} \mathrm{C}$ and $12: 12$ light: dark cycle, respectively. The fish were fed with the experimental diets three times daily at 8:00 a.m., 12:00 p.m. and 4:00 p.m. to apparent satiation for a period of eight weeks. During the feeding period, $25 \%$ of the water in each aquarium was replaced with freshwater every day. The feces were also siphoned after one hour of feeding. Temperature, 
dissolved oxygen and $\mathrm{pH}$ of water in each aquarium were recorded during the eight weeks of experiment using a portable multi-meter (AZ-8603, model) as $25 \pm 2.3^{\circ} \mathrm{C}, 6.25 \pm 0.65 \mathrm{mg} \mathrm{L}^{-1}$ and $7.30 \pm 0.6$, respectively.

\subsection{Assessment of growth performance}

In the present study, we analyzed the effects of two forms of dietary SP on the growth performance and survival of fish through measurement of final length and weight of fish in each aquarium at the end of feeding trial. The parameters of growth performance and also the survival rate of fish determined using the following formula:

Weight gain $(\mathrm{g})=[($ final body weight $(\mathrm{g})-$ initial body weight $(\mathrm{g}) /$ initial body weight $(\mathrm{g})] \times 100$

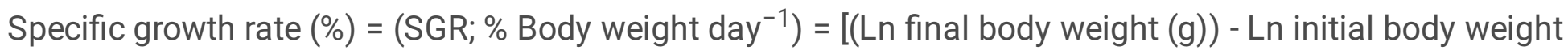
(g))/ Time (day) $] \times 100$

Daily growth index (DGI) $(\mathrm{g})=[($ final body weight $(\mathrm{g})$ - initial body weight $(\mathrm{g})) /$ Time $($ day $)]$

Feed conversion ratio $(\mathrm{FCR})=($ Feed consumed $(\mathrm{g}) /$ Weight gain $(\mathrm{g}))$

Condition factor $(\mathrm{CF})\left(\mathrm{g} \mathrm{cm}^{-3}\right)=\left[\right.$ final weight $(\mathrm{g}) /$ final length $\left.(\mathrm{cm})^{3}\right] \times 100$

Survival rate $(\%)=($ final number of fish $/$ initial number of fish $) \times 100$

\subsection{Digestive enzymes assessment}

At the end of feeding experiment, the fish were starved for $24 \mathrm{~h}$ and then, three fish randomly selected from each aquarium and anaesthetized individually using ground clove oil $\left(80 \mathrm{mg} \mathrm{L}^{-1}\right)$. Then, intestine tissue was removed from the body of each fish and rinsed with cold distilled water $\left(4^{\circ} \mathrm{C}\right)$ (Huang et al., 1999). Tissue homogenization was performed by a homogenizer (IKA T25 model) in $0.2 \mathrm{M} \mathrm{NaCl}(1: 5$; w/v) (Gawlicka et al., 2000). Homogenates were centrifuged $\left(15000 \times \mathrm{g}, 4^{\circ} \mathrm{C}\right)$ for $15 \mathrm{~min}$ and supernatants were kept at $-80^{\circ} \mathrm{C}$ and used for measurement of digestive enzymes activities using an ultraviolet visible spectrophotometer (DR 5000 ${ }^{\mathrm{TM}}$ model, $\mathrm{HACH}$ CO., USA). Results were reported as $\mathrm{U} \mathrm{mg}^{-1}$ protein $\mathrm{min}^{-1}$.

Protease activity was assayed according to the casein-hydrolysis method (Hidalgo et al., 1999). In this method, $0.05 \mathrm{~mL}$ of the supernatant of each homogenate was mixed with $0.125 \mathrm{~mL}$ of casein $(1 \% \mathrm{w} / \mathrm{v})$ and $0.125 \mathrm{~mL}$ of buffer $(0.1 \mathrm{M}$ Tris- $\mathrm{HCl}, \mathrm{pH} 9.0)$ and incubated at $37^{\circ} \mathrm{C}$ for $1 \mathrm{~h}$. To stop the reaction, trichloroacetic acid (TCA) solution $(8 \% \mathrm{w} / \mathrm{v} ; 0.3 \mathrm{~mL})$ was added to the solution. The samples were kept at $4^{\circ} \mathrm{C}$ for $1 \mathrm{~h}$ and then, were centrifuged at $1800 \times \mathrm{g}$ for $10 \mathrm{~min}$. Finally, the absorbance of supernatant was measured at $280 \mathrm{~nm}$.

The method of Erlanger et al. (1961) was followed for the measurement of trypsin activity in the intestine homogenate. The N-a-benzoyl-dlarginine-pnitroanilide (BAPNA) as substrate. The BAPNA (1 mM) was added to $20 \mathrm{mM}$ of $\mathrm{CaCl}_{2}$ and $50 \mathrm{mM}$ of Tris- $\mathrm{HCl}, \mathrm{pH}$ 8.2. It was incubated with the enzyme extract in the supernatant at $25^{\circ} \mathrm{C}$. The production of nitroaniline was measured at $410 \mathrm{~nm}$. 
The a-amylase activity was determined based on the method of the 3,5-dinitrosalicylic acid using soluble starch ( $1 \% \mathrm{w} / \mathrm{v}$ ) prepared in $0.02 \mathrm{M} \mathrm{Na}_{2} \mathrm{HPO}_{4}, \mathrm{pH} 6.9$ with $0.006 \mathrm{M} \mathrm{NaCl}$ as substrate (Worthington, 1991). One unit of activity was defined as one micromole of maltose released in per minute. The absorbance was measured at $540 \mathrm{~nm}$.

Lipase activity was assayed based on the method detailed by Gawlicka et al. (2000) using $0.4 \mathrm{mM}$ of pnitrophenylmyristate as a substrate at $25^{\circ} \mathrm{C}$ and a wavelength of $405 \mathrm{~nm}$.

The activity of alkaline phosphatase (ALP) enzyme was determined using a commercial kit (Pars Azmoon Company, Iran) at optical density (OD) of $405 \mathrm{~nm}$.

\subsection{Immunological assessment}

The activity of immunological parameters including total immunoglobulin (Ig), lysozyme and alternative complement pathway hemolytic activity (ACH50) were assayed in skin mucus of fish. Collection of skin mucus was performed according to the protocol described by Subramanian et al. (2007). Briefly, fish were starved for $24 \mathrm{~h}$ at the end of feeding trail and three specimens were randomly sampled from each glass aquarium. The sampled fish were anesthetized using clove oil $\left(80 \mathrm{mg} \mathrm{L}^{-1}\right)$ and then transferred individually into a polyethylene bag containing $\mathrm{NaCl}$ solution (50 mM; $5 \mathrm{~mL} \mathrm{~g}^{-1}$ fish; Merck, Germany). Fish was rubbed slowly inside the plastic bag for 1-2 min to collect the skin mucus. The collected mucus was immediately poured into a tube test $(15 \mathrm{~mL})$, centrifuged $\left(1500 \times \mathrm{g}\right.$ for $10 \mathrm{~min}$ at $\left.4^{\circ} \mathrm{C}\right)$ and obtained supernatant was stored at $-80^{\circ} \mathrm{C}$ for future analysis.

The skin mucus total immunoglobulin (lg) was determined according to the procedure suggested by Siwicki et al. (1994). Firstly, the total protein content of each skin mucus sample was measured based on the standard method described by Lowry et al. (1951). In following, Ig molecules were precipitated using a $12 \%$ solution of polyethylene glycol and the amount of total protein in each sample was re-measured. The difference in two measured protein contents was calculated as the total Ig content.

The lysozyme activity of samples was determined by the lysis of the lysozyme sensitive Gram-positive bacterium, Micrococcus luteus as explained by Hoseninifar et al. (2016).Briefly, lysozyme-sensitive Grampositive bacterium Micrococcus luteus (50 $\mathrm{LL}$, Sigma, USA) suspension was prepared using $0.02 \mathrm{M}$ sodium acetate buffer with pH $5.8\left(0.02 \mathrm{mg} \mathrm{L}^{-1}\right)$, transferred into a 96 well plate and then $50 \mu \mathrm{L}$ of mucus sample was poured in each wall. After incubation of well plates at $30^{\circ} \mathrm{C}$ for $15 \mathrm{~min}$, the OD of sample was monitored at $450 \mathrm{~nm}$ twice with an interval of 50 min using a spectrophotometer (DR $5000^{\mathrm{TM}}$ model, $\mathrm{HACH}$ CO., USA). The difference between absorbance values was calculated as amount of lysozyme activity $\left(\mathrm{U} \mathrm{mL}^{-1}\right)$.

The method explained by Yano (1992) was applied for measurement of alternative complement pathway hemolytic activity (ACH50) of samples. Briefly, diluted skin mucus samples from 50 to $250 \mu \mathrm{L}$ was poured in tube tests and barbitone buffer in the presence of ethyleneglycol-bis (2-aminoethoxy)tetraacetic acid (EGTA) and $\mathrm{Mg}^{2+}$ was added to increase the total volume of each tube test to $250 \mu \mathrm{L}$. 
Then, $100 \mu \mathrm{L}$ of New Zealand Rabbit Red Blood Cells (RaRBC) was allotted into each tube test and incubated for $90 \mathrm{~min}$ at $20^{\circ} \mathrm{C}$. In following, $3.15 \mathrm{~mL} \mathrm{NaCl}$ was added to each tube test and centrifuged for $5 \mathrm{~min}$ at $1600 \times \mathrm{g}$. The $\mathrm{OD}$ of obtained supernatant was read at $414 \mathrm{~nm}$. The number of $A C H 50 \mathrm{unit} \mathrm{mL}^{-1}$ was determined based on the skin mucus volume producing $50 \% \mathrm{ACH}$.

\subsection{Liver enzymatic analysis}

The liver enzymes activities were measured in the sampled fish at the end of the feeding experiment. The liver tissues of the fish were removed, washed with ice-cold $0.95 \%$ saline and homogenized in presence of ice-cold 0.1 M Tris HCL buffer ( $\mathrm{pH}$ 7.1) with using a glass homogenizer. In following, the homogenized tissues were centrifuged (1000 rpm, $4^{\circ} \mathrm{C}$ for $10 \mathrm{~min}$ ) and the obtained supernatants were stored at $-80^{\circ} \mathrm{C}$ to measure the liver enzymes in the future (Jindal et al., 2018).

Aspartate aminotransferase (AST) and alanine aminotransferase (ALT) activities were determined based on colorimetric method described by Frankel-Reitman method (Reitman and Frankel, 1957) using commercial kits (Ziest Chem Diagnostic Co., Tehran, Iran) at a wavelength of $505 \mathrm{~nm}$.

Superoxide dismutase (SOD) activity was measured according to the procedure explored by Marklund and Marklund (1974). Briefly, the reaction mixture was prepared by mixing $30 \mu \mathrm{L}$ of homogenate supernatant with $2 \mathrm{~mL}$ of Tris- $\mathrm{HCl}(50 \mathrm{mM}, \mathrm{pH}=8.2)$. The reaction was followed by adding $20 \mu \mathrm{L}$ of pyrogallol solution $(10 \mathrm{mM}, \mathrm{pH}=7.4)$. Then, autoxidation of the pyrogallol was compared with the control at a wavelength of $420 \mathrm{~nm}$ and the SOD concentration was determined through $50 \%$ inhibition of pyrogallol oxidation.

Catalase (CAT) activity was measured according to the methodology of Aebi (1984) using hydrogen peroxide $\left(\mathrm{H}_{2} \mathrm{O}_{2}\right)$ as a substrate. Briefly, the reaction solution was prepared through combination of $50 \mathrm{mM}$ $\mathrm{H}_{2} \mathrm{O}_{2}$ in $50 \mathrm{mM}$ potassium phosphate buffer. Afterwards, the decomposition of $\mathrm{H}_{2} \mathrm{O}_{2}$ by CAT enzyme were determined using spectrophotometer at $\mathrm{OD}$ of $240 \mathrm{~nm}$ at $\mathrm{pH}=7$.

The activity of alkaline phosphatase (ALP) was examined using a commercial kit (Pars Azmoon Company, Iran) at OD of $405 \mathrm{~nm}$.

\subsection{Statistical analysis}

Data were presented as mean \pm standard deviation (SD). SPSS software (Version, 19) was applied for statistical analysis. The normality assumption of data was assayed by performing the KolmogorovSmirnov test. Significant differences between means at $P<0.05$ were determined by subjecting the data to One-Way Analysis of Variance (ANOVA) followed by Duncan's New Multiple Range test.

\section{Results}

\subsection{Characterization of synthetized MIP-SP particles}


Synthetized MIP-SP particles with small spherical shape are shown in Fe-SEM and TEM micrographs (Fig. 1a, c). The loading of SP into MIP particles was confirmed by the presence of sodium $\left(\mathrm{Na}^{+}\right)$ions in the EDS analysis (Fig. 1b). The measurement of particle sizes on TEM micrographs showed that the particles had mean diameter of $61.22 \pm 13.90 \mathrm{~nm}$ with the size distribution of 27.87 to $98.97 \mathrm{~nm}$ (Fig. 1c, d). Based on the result of ICP-OES, the amount of SP loaded into MIP nanoparticles was $8.5 \%$.

Figure 2 shows the FT-IR spectra obtained for MIP-SP NPs. As it is seen, the typical acrylic polymer bands can be clearly observed in the FT-IR spectrum. The appeared signal at $3524 \mathrm{~cm}^{-1}$ are attributed to the presence of $\mathrm{O}-\mathrm{H}$ stretching. The bending vibration of hydroxyl group is also observed at $1390.7 \mathrm{~cm}^{-1}$. The strong signal in the spectral region of $1726 \mathrm{~cm}^{-1}$ can be assigned to the $\mathrm{C}=0$ functional groups at propionate, methacrylic acid and acrylic ester. The signals appeared at $1262.4 \mathrm{~cm}^{-1}$ and $1154.6 \mathrm{~cm}^{-1} \mathrm{for}$ the symmetric and asymmetric $\mathrm{C}-0$ stretch bands. Other important absorption peaks were shown at 1640 $\mathrm{cm}^{-1}$ and $964.6 \mathrm{~cm}^{-1}$ are attributed to the presence of stretching and out of plane vibration of residual vinylic $\mathrm{C}=\mathrm{C}$ and $\mathrm{C}-\mathrm{H}$ bonds, respectively.

\subsection{Growth performance}

Table 2 shows the growth parameters and survival rate of African cichlid fingerlings fed with diets supplemented with two forms of sodium propionate for 8 weeks. No significant difference was observed between the initial weight of fish in different dietary groups $(P>0.05)$. The final weight $(F W)$, weight gain (WG), specific growth rate (SGR) and daily growth index (DGI) of fish increased in SP dietary groups compared to control groups $(P>0.05)$. The highest $F W, W G$ and $D G I$ indices were observed in the MIP-SP NPs dietary group $(P<0.05)$. The FCR value decreased in the fish fed on SP-supplemented diets compared to the controls $(P<0.05)$. Fish fed on MIP-SP NPs-supplemented diet showed the lowest FCR $(P<0.05)$. The condition factor (CF) parameter and survival rate (\%) showed no significant differences between the dietary groups $(P>0.05)$.

\subsection{Digestive enzymes assays}

The effects of different SP-supplemented diets on the digestive enzymes activities are presented in Table 3. The protease, trypsin, lipase and alkaline phosphatase activities were higher in the SP dietary groups than the control groups $(P<0.05)$. The protease and lipase activities were significantly higher in the MIPSP NPs dietary group than the P-SP dietary group $(P<0.05)$. No significant difference in the a-amylase activity was observed between different dietary groups $(P>0.05)$.

\subsection{Immunological analyses}

Figure 3 (a-c) shows the changes of the skin mucus immune parameters in the fish fed with SPsupplemented diets. The total immunoglobulin (Ig), lysozyme (LYZ) and alternative haemolytic complement (ACH50) activities were higher in the SP dietary groups than the control groups $(P<0.05)$. The highest levels of these indices were observed in the MIP-SP NPs dietary group $(P<0.05)$.

\subsection{Liver enzymatic assessment}


Figure 4 (a-e) shows the liver enzyme levels in the fish fed on SP-supplemented diets. The alanine aminotransferase (ALT) and the aspartate aminotransferase (AST) levels decreased significantly in the SP-supplemented dietary groups in comparison to the control groups $(\mathrm{P}<0.05)$ (Fig. 4a-b). The SP-dietary groups showed the higher superoxide dismutase (SOD), catalase (CAT) and alkaline phosphatase (ALP) levels than the controls $(P<0.05)$. The SOD and ALP levels in the fish fed on MIP-SP NPs-supplemented diet were higher than those fed on P-SP-supplemented diet $(P<0.05)$ (Fig. 4c, e).

\section{Discussion}

Encapsulation of pharmaceutical agents in a carrier can be considered as a suitable approach to improve their efficiency for aquatic animals by slow and controlled release and reducing leaching. Two major types of carriers for targeted or non-targeted drug delivery are included inorganic and organic carriers such as synthetic polymers (Senapati et al., 2018). Polymeric nanoparticles made from synthetic polymers or from natural polymers are biocompatible and often biodegradable systems that commonly used for nanomedicine applications (Park et al., 2008; Senapati et al., 2018). In the current study, sodium propionate (SP) was encapsulated in the nanoparticles of molecular imprinted polymer (MIP) as a drug delivery vehicle. The characterization of synthetized particles showed that the MIP particles were nanoscale with mean diameter of $61.22 \pm 13.0 \mathrm{~nm}$ and loaded with SP (8.5\%). The effects of dietary MIPSP NPs on the survival, growth, digestive and antioxidant enzymes activity and skin mucus indices of African cichlid (L. lividus) fingerlings compared to powder form of sodium propionate (P-SP) were investigated.

Feeding the African cichlid fingerlings with SP-supplemented diets at level of $5 \mathrm{~g} \mathrm{Kg}^{-1}$ of dry diet for 56 days resulted in enhancement of growth performance including final weight, WG, SGR(\%), DGI and FCR. Several studies have attributed the improvement of nutrient utilization and growth performance of aquatic animals fed on diets containing organic acids and their salts to reduction of the digesta $\mathrm{pH}$ (Chowdhury et al., 2021), changes in microbial population of the intestinal tract ( $\mathrm{Ng}$ and Koh, 2016), stimulation of digestive enzyme secretion (Chowdhury et al., 2021) and increased feed intake (Da Silva et al., 2015; Omosowone et al., 2018). Omosowone et al. (2018) showed that Clarias gariepinus and Oreochromis niloticus fingerlings fed $2 \%$ butyric acid-supplemented diet for 12 weeks had better feed utilization and growth performance. Feeding red sea bream Pagrus major with $1 \%$ citric acid improved weight gain and FCR values and absorption of phosphorus from dietary components (Hossain et al., 2007). Organic acid might influence on digestibility of protein and amino acids and absorption of minerals in growing pigs (Partenen et al., 1999).

The administration of encapsulated form of SP had significantly greater effect on the final weight, WG, DGI and FCR compared to the powder form of SP. Nanoencapsulation of bioactive ingredients improve their bioavailability due to the increase of surface-to-volume ratio of nanocarrier, enhance their interaction with metabolism and enzyme factors and allow them to pass through cell walls (McClements and Jafari, 2018; Jafari et al., 2017). Nanocarries protect bioactive ingredients from premature degradation in the biological environment, increase cellular uptake and prolong their presence in the blood (Kumari et al., 
2010). Safari et al. (2021) reported that dietary administration of encapsulated organic salts (Na-acetate, Na-butyrate, Na-lactate and Na-propionate) at level of $20 \mathrm{~g} \mathrm{~kg}^{-1}$ improved the growth performance and survival of crawfish (Astacus leptodactylus leptodactylus). Chow et al. (2017) attributed the improved growth performance of hybrid catfish (Clarias macrocephalus $\times$ Clarias gariepinus) fed on encapsulated butyric acid (ButiPEARL)-supplemented diet to slow release of the butyric acid in the gastrointestinal tract. They stated the better villi growth in the small intestine due to more accessibility of butyric acid and thus better digestibility of nutrients. Kalantarian et al. (2020) reported that feeding Salmo trutta caspius juveniles with diets supplemented with 5,10 and $15 \mathrm{~g}$ sodium diformate $\mathrm{kg}^{-1}$ diet for 60 days led to a significant increase in villi height in proximal area of intestine.

One of the possible reasons for the improvement of growth performance of African cichlid fingerlings fed on SP-supplemented diets is probably due to the increased activity of digestive enzymes including trypsin, protease, alkaline phosphatase and lipase. The increase in trypsin, protease and lipase activities in $S$. trutta caspius fed with sodium diformate-supplemented diets for 60 days were also reported (Kalantarian et al., 2020). The increase in digestive enzymes activity might be due to the secretion of secretin in result of acidification of the gastrointestinal tract ( $\mathrm{Ng}$ and Koh, 2016). The findings of current study indicated more positive effect of encapsulated sodium propionate on the activities of protease and lipase enzymes in comparison to its powder form. Nanoparticles delivery system enhances absorption of encapsulate bioactive compounds in the gastrointestinal tract through active endocytosis (des Rieux et al., 2006). Internalized nanoparticles in epithelial cells may be translocated to endo/lysosome and degraded in lysosome to release their contents or may remain intact in endolysosome and enter blood circulation by exocytosis (Qian et al., 2009; Li et al., 2014). Encapsulation of bioactive compounds is a practical approach for slow release and delivering them at the intended location of the gastrointestinal tract (Piva et al., 2007; Chen et al., 2017). Tian et al. (2017) found that microencapsulated sodium butyrate (MSB) had superior effect on improvement of the trypsin, lipase, amylase and chymotrypsin activities compared to powder sodium butyrate (PSB) in grass carp (Ctenopharyngodon idella).

Disease outbreaks are considered to be a major challenge for the expansion of aquaculture industry due to causing significant economic losses (Opiyo et al., 2018). Fish have developed several mechanisms to fight pathogenic microorganisms which inhabit the aquatic environments (Cámara-Ruiz et al., 2021). The mucosal surfaces including gill, skin, gut and olfactory organ which coated by a mucosal layer provide the first line of defense mechanism in aquatic organisms (Rombout et al., 2011; Benhamed et al., 2014). The mucosal layer contains potent bioactive molecules such as antimicrobial peptides, lysozyme, complement proteins, immunoglobulins, lectins and haemolysins (Palaksha et al., 2008; Nigam et al., 2012). Several studies have evaluated the effects of different feed additives such as organic acids and their salts on enhancement of innate immune system in aquatic organisms (Safari et al., 2016; Busti et al., 2020; Chowdhury et al., 202). The organic acids like propionate and acetate can act as ligands for $\mathrm{G}$ protein-coupled receptor 43 and thus modulate fish immunity (Maslowski and Mackay, 2011). Sotoudeh et al. (2020) reported that administration of diets supplemented with blends of organic acids (sodium propionate and sodium acetate) for eight weeks increased plasma lysozyme and ACH50 of yellowfin 
seabream (Acanthopagrus latus) juveniles. Safari et al. (2017) also showed up-regulation of immunerelated genes expression which was associated with increasing lysozyme activity and Ig level in the skin mucus of common carp (C. carpio) fed with SP-supplemented dies for eight weeks. The findings of our study also showed that inclusion of two different forms of SP into diet increased significantly the lysozyme and total Ig levels and ACH50 activity in the skin mucus. The administration of SP in nanoencapsulate form showed the greater incremental effects on the mucosal immunity of African cichlid. Busti et al. (2020) stated that encapsulated organic acids and nature identical compounds are protected from degradation in the stomach and arrive intact in the intestine tract where they exert their effects on gut microbiota f European sea bass juveniles. Some studies have reported that gut microbiota plays criteria roles in regulation of innate immunity in fish (Gómez and Balcázar, 2008; Nie et al., 2017). Abu Elala and Ragaa. (2014) reported the modification of beneficial intestinal flora in gut of tilapia (Oreochromis niloticus) after feeding with $0.3 \%$ potassium diformate (KDF), which resulted in the activation of humeral and cellular innate immune responses.

AST and ALT enzymes are found in kidney, heart, muscles and mainly in liver cells (Rastiannasab et al., 2016). Function of these enzymes is to metabolize protein and breakdown food to produce energy and their tissue activities are markers for liver function (Metón et al., 2015; Rastiannasab et al., 2016). Increased AST and ALT levels in the liver and blood indicate damage to liver cells (Huang et al., 2006; Rastiannasab et al., 2016). The findings of current study showed that feeding the African cichlid fingerlings with diets supplementation with MIP NPs and different forms of SP did not increase AST and ALT levels in the liver tissue. These results indicated that the supplemented diets had no detrimental effect on the function of liver tissue. Agouz et al. (2015) also found that ALT and AST levels did not increased significantly in blood of Nile tilapia $O$. niloticus fed on diets contained $1 \%$ and $1.5 \%$ of two organic acid salts (calcium lactate + sodium acetate, 1:1) blend in comparison to the control group.

Alkaline phosphatase (ALP) is known as a polyfunctional enzyme that possess a vital role in the membrane transport activities, mineralization of the skeleton of aquatic organisms (Zikic et al., 2001), growth and synthesis of protein (Ram and Sathyanesan, 1985). Administration of dietary encapsulated organic acid significantly increased ALP level in the serum of Pacific White Shrimp (Litopenaeus vannamei) compared to the control group (Chowdhury et al., 2021). In the present study, the liver ALP level increased significantly in the SP dietary groups.

Fish, like all aerobic organisms that are exposed to the attack of reactive oxygen species have an antioxidant defense system (Trenzado et al., 2006). Several factors such as feeding behavior and environmental parameters can either enhance or weaken the antioxidant defense response in fish and shellfish (Martínez-Álvarez et al., 2005; Hoseinifar et al., 2020 ). Some studies have reported the beneficial effects of feed additives such as probiotics, prebiotic, and synbiotic on the promotion of antioxidant enzyme activity in different fish species (Dawood et al. 2018; Van Doan et al. 2020). Up-regulation in genes of glutathione peroxidase (GPx), glutathione-disulphide reductase (GSR), glutathione S-transferase (GSTA) as antioxidant enzymes was noticed in liver of common carp (C. carpio) fed on diets containing $1 \%$ and $2 \%$ of SP (Safari et al., 2017). Chiu et al. (2008) also found an increase in SOD activity in juvenile 
of grouper, fish (Epinephelus fuscoguttatus) fed on diets containing 1.0 and $2.0 \mathrm{~g} \mathrm{~kg}^{-1}$ of sodium alginate. In the present study, our findings showed that administration of different forms of SP in the diets at the level of $5 \mathrm{~g} \mathrm{Kg}^{-1}$ increased significantly the liver SOD and CAT activity. In contrast to these results, Safari et al. (2016) showed down-regulation of CAT and SOD genes in liver of zebra fish (Danio rerio) fed with diets supplemented with 5,10 and $20 \mathrm{~g} \mathrm{SP} \mathrm{Kg}$ of diet.

Bioavailability of antioxidant molecules is limited due to the difficulty of passing through the cell membranes and degradation during delivery to tissues. Nano-encapsulated antioxidant molecules provide advantages such as increased bioavailability and controlled release of antioxidants (Khalil et al., 2020). The findings of our study revealed that the liver SOD activity increased in the fish fed on MIP-SP NPs-supplemented diet compared to those fed with P-SP-supplemented diet.

\section{Conclusion}

This study was conducted to compare the effects of two forms of sodium propionate on the growth performance, mucosal immune response, and digestive and liver enzymes activities of African cichlid ( $L$. lividus) fingerlings. According to the results, it can be concluded that sodium propionate encapsulated in molecular imprinted polymer (MIP) nanoparticles showed higher efficiency compared to powder sodium propionate to improve growth performance and mucosal immune response in African cichlid fingerlings. It is recommended to use modified MIP nanoparticles as an effective strategy for active delivery of pharmaceutical compounds to the target sites in fish and shellfish species.

\section{Declarations}

\section{Acknowledgements}

The authors thank the staff of the Faculty of Natural Resources and Environment of Ferdowsi University of Mashhad (FUM) for their cooperation in conducting this research.This study was financially supported by a grant from Ferdowsi University of Mashhad (No. 2/47528).

\section{Conflict of interest}

The authors declare that there are no conflicts of interest.

\section{Ethics approval}

The all experiments on fish were performed according to Ferdowsi University of Mashhad (FUM) animal ethic right and Directive 2010/63/EU of the European Parliament and of the Council of 22 September 2010 on the protection of animals.

\section{Data availability statement}

The data of this study are available on reasonable request from the corresponding author. 
ORCID

Mehrdad Sarkheil. http://orcid.org/0000-0003-4799-4658

\section{Funding:}

This work was supported by a grant from Ferdowsi University of Mashhad (No. 2/47528).

\section{Conflicts of interest/Competing:}

The authors declare that they have no known competing financial interests or personal relationships that could have appeared to influence the work reported in this paper.

\section{Ethics approval:}

The all experiments on fish were performed according to Ferdowsi University of Mashhad (FUM) animal ethic right and Directive 2010/63/EU of the European Parliament and of the Council of 22 September 2010 on the protection of animals.

\section{Consent to participate:}

Not applicable

\section{Consent for publication:}

Not applicable

\section{Availability of data and material:}

All data and materials are included in this published article.

\section{Code availability:}

Not applicable

\section{Authors' contributions:}

Mehrdad Sarkheil: Supervision, Conceptualization, Methodology, Data collection, Project administration, Writing- Original draft preparation; Omid Safari: Writing - Review \& Editing; Davood Kordestani: Conceptualization, Methodology, Writing - Review \& Editing. All authors read and approved the final version. All authors read and approved the final manuscript.

\section{References}

1. Abu Elala NM, Ragaa NM (2015) Eubiotic effect of a dietary acidifier (potassium diformate) on the health status of cultured Oreochromis niloticus. J Adv Res 6:621-629 
2. Aebi H (1984) Catalase in vitro. Meth Enzymol 105:121-126

3. Agouz HM, Soltan MA, Meshrf RN (2015) Effect of some organic acids and organic salt blends on growth performance and feed utilization of Nile tilapia (Oreochromis niloticus). Egyptian Journal of Nutrition and Feeds. 18 (2) Special Issue, 443-450

4. AOAC., Official Methods of Analysis, 18th ed.AOAC International, Maryland, USA

5. Asadi E, Abdouss M, Leblanc RM, Ezzati N, Wilson JN, Kordestani D (2016) Synthesis, characterization and in vivo drug delivery study of a biodegradable nano-structured molecularly imprinted polymer based on cross-linker of fructose. Polymer doi. 10.1016/j.polymer.2016.05.031

6. Baruah K, Norouzitallab P, Debnath D, Pal AK, Sahu NP (2008) Organic acids as non-antibiotic nutraceuticals in fish and prawn feed. Aquaculture Health International. March 2008

7. Baruah K, Pal AK, Sahu NP, Jain KK, Mukherjee SC, Debnath D (2005) Dietary protein level, microbial phytase, citric acid and their interactions on bone mineralization of Labeo rohita (Hamilton) juveniles. Aquac Res 36:803-812

8. Benhamed S, Guardiola FA, Mars M, Esteban M (2014) Pathogen bacteria adhesion to skin mucus of fishes. Vet Microbiol 171:1-12

9. Boland FE, Lin RC, Mulvaney TR, Mcclure FD, Johnston MR (1981) pH Determination in Acidified Foods: Collaborative Study. Journal of Association of Official Analytical Chemists 46(2):332-336. doi: 10.1093/jaoac/64.2.332

10. Booth IR, Stratford M (2003) Acidulants and low pH., in: In: Russel NJ, Gould GW (eds) Food Preservatives. Kluwer Academic/Plenum Publishers, New York, pp 25-47

11. Busti S, Rossi B, Volpe E, Ciulli S, Piva A, Amico FD, Soverini M, Candela M, Gatta PP, Bonaldo A, Grilli E, Parma L (2020) Effects of dietary organic acids and nature identical compounds on growth, immune parameters and gut microbiota of European seabass. Sci Rep 10:21321. doi: $10.1038 / \mathrm{s} 41598-020-78441-9$

12. Cabello FC, Godfrey HP, Tomova A (2013) Antimicrobial use in aquaculture re-xamined: its relevance to antimicrobial resistance and to animal and human health. Environ Microbial 15:1917-1942

13. Cámara-Ruiz M, Carmen Balebona B, Moriñigo MA, Esteban MA (2020) Probiotic Shewanella putrefaciens (SpPdp11) as a Fish Health Modulator: A Review. Microorganisms. 8, 1990. doi:10.3390/microorganisms8121990

14. Cámara-Ruiz M, Cerezo IM, Guardiola FA, García-Beltrán JM, Balebona MC, Moriñigo M, Esteban M (2021) Alteration of the Immune Response and the Microbiota of the Skin during a Natural Infection by Vibrio harveyi in European Seabass (Dicentrarchus labrax). Microorganisms 9:964. doi:10.3390/microorganisms9050964

15. Castillo S, Rosales M, Pohlenz C, Gatlin DM (2014) Effects of organic acids on growth performance and digestive enzyme activities of juvenile red drum Sciaenops ocellatus. Aquaculture 433:6-12

16. Chen J, Wang Q, Liu CM, Gong J (2017) Issues deserve attention in encapsulating probiotics: Critical review of existing literatures. Crit Rev Food Sci Nut 57:1228-1238 
17. Chiu ST, Tsai RT, Hsu JP, Liu CH, Cheng W (2008) Dietary sodium alginate administration to enhance the non-specific immune responses, and disease resistance of the juvenile grouper Epinephelus fuscoguttatus. Aquaculture 27:66-72

18. Chow EPY, Liong KH, Schoeters E (2017) Dietary encapsulated butyric acid (Butipearl ${ }^{\mathrm{TM}}$ ) and microemulsified carotenoids (Quantum GLO ${ }^{\mathrm{TM}} \mathrm{Y}$ ) on the growth, immune parameters and their synergistic effect on pigmentation of hybrid Catfish (Clarias macrocephalus $\times$ Clarias gariepinus). $\mathrm{J}$ fish aquac 8(2). doi: 10.4172/2150-3508.1000195

19. Chowdhury MAK, Song H, Liu Y, Bunod JD, Dong XH (2021) Effects of microencapsulated organic acid and their Salts on growth performance, immunity, and disease resistance of Pacific White Shrimp Litopenaeus vannamei. Sustainability 13:7791. doi:10.3390/su13147791

20. Cunliffe D, Kirby A, Alexander C (2005) Molecularly imprinted drug delivery systems. Adv Drug Deliv 57:1836-1853

21. Da Silva BC, Vieira FN, Mourino JLP, Bolivar N, Seiffert WQ (2015) Butyrate and propionate improve the growth performance of Litopenaeus vannamei. Aquac Res 4(2):7. doi: org/10.1111/are.12520

22. Dawood MAO, Koshio S, Esteban MA (2018) Beneficial roles of feed additives as immunostimulants in aquaculture: a review. Rev Aquacult 10(4):950-974. doi:10.1111/raq.12209

23. Defoirdt T, Boon N, Sorgeloos P, Verstraete W, Bossier P (2009) Short-chain fatty acids and poly- $\beta$ hydroxyalkanoates: (New) Biocontrol agents for a sustainable animal production. Biotech Advan 27:680-685

24. Erlanger BF, Kokowsky N, Cohen W (1961) The preparation and properties of two new chromogenic substrates of trypsin. Arch Biochem Biophys 95:271-278. doi:10.1016/0003-9861(61)90145-X

25. Gao L, Wang J, Li X, Yan Y, Li C, Pan J (2014) A core-shell surface magnetic molecularly imprinted polymers with fluorescence for $\lambda$-cyhalothrin selective recognition. Anal Bioanal Chem 406:72137220. doi:10.1007/s00216-014-8126-8

26. Gao Y, Storebakken T, Shearer KD, Penn M, Øverland M (2011) Supplementation of fishmeal and plant-protein based diets for rainbow trout with a mixture of sodium formate and butyrate. Aquaculture 211:233-240

27. Gawlicka A, Parent B, Horn MH, Ross N, Opstad I, Torrissen OJ (2000) Activity of digestive enzymes in yolk-sac larvae of Atlantic halibut (Hippoglossus hippoglossus): indication of eadiness for first feeding. Aquaculture 184:303-314. doi:10.1016/S0044-8486(99)00322-1

28. Gómez GD, Balcázar JL (2008) A review on the interactions between gut microbiota and innate immunity of fish. FEMS Microbiol Immunol 52(2):145-154

29. He W, Rahimnejad S, Wang L, Song K, Lu K, Zhang C (2017) Effects of organic acids and essential oils blend on growth, gut microbiota, immune response and disease resistance of Pacific white shrimp (Litopenaeus vannmei) against Vibrio parahaemolyticus. Fish Shellfish Immunol 70:164-173

30. Hidalgo MC, Urea E, Sanz A (1999) Comparative study of digestive enzymes in fish with different nutritional habits: Proteolytic and amylase activities. Aquaculture 170:267-283 
31. Hoseinifar SH, Sun Y-Z, Caipang CM (2016 b) Short chain fatty acids as feed supplements for sustainable aquaculture: an updated view. Aquac. Res.doi:10.1111/are.13239

32. Hoseinifar SH, Yousefi S, Van Doan H, Ashouri G, Gioacchini G, Maradonna F, Carnevali O (2020) Oxidative Stress and Antioxidant Defense in Fish: the implications of probiotic, prebiotic, and synbiotics. Rev Fish Sci Aquac. doi: 10.1080/23308249.2020.1795616

33. Zoheiri SH, Caipang F, C.M (2016a) Dietary sodium propionate improved performance, mucosal and humoral immune responses in Caspian white fish (Rutilus frisii kutum) fry. Fish Shellfish Immunol 55:523-528

34. Hossain MA, Pandey A, Satoh S (2007) Effects of organic acids on growth and phosphorus utilization in red sea bream Pagrus major. Fish Sci 73:1309-1317. doi: 10.1111/j.14442906.2007.01469.x

35. Huang F, Yan A, Mu S, Wang X (1999) The protease and amylase of Hypophthalmichthy molitrix and Aristichthys nobilis. Journal of Fishery Sciences of China 6(2):14-17

36. Huang XJ, Choi YK, Im HS, Yarimaga O, Yoon E, Kim HS (2006) Aspartate aminotransferase (AST/GOT) and alanine aminotransferase (ALT/GPT) detection techniques. Sensors 6:756-782

37. Jafari SM, McClements DJ (2017) Chapter One - Nanotechnology approaches for increasing nutrient bioavailability. Advances in Food and Nutrition Research, vol 81. Academic Press,. 378p. Cambridge, United States, pp 1-30. doi: 10.1016/bs.afnr.2016.12.008

38. Jaiswal L, Rakkit S, Pochin K, Jaisamut P, Tanthana C, Tanmanee N (2015) A thalidomide templated molecularly imprinted polymer that promotes a biologically active chiral entity tagged in colon carcinoma cells and protein-related immune activation. Process Biochem 50:2035-2050. doi:10.1016/j.procbio.2015.09.016

39. Jindal R, Sinha R, Brar P (2018) Evaluating the protective efficacy of Silybum marianum against deltamethrin induced hepatotoxicity in piscine model. Environ Toxicol Pharmacol. doi:10.1016/j.etap.2018.12.014

40. Kalantarian SH, Mirzargar SS, Rahmati-Holasoo H, Sadeghinezhad J, Mohammadian T (2021) Effects of oral administration of acidifier and probiotic on growth performance, digestive enzymes activities and intestinal histomorphology in Salmo trutta caspius (Kessler, 1877). Iran J Fish Sci 19(3):1532-1555

41. Khalil I, Yehye WA, Etxeberria AE, Alhadi AA, Dezfooli SM, Julkapli NBM, Basirun WJ, Seyfoddin A (2020) Nanoantioxidants: recent trends in antioxidant delivery applications. Antioxidants 9:24. doi:10.3390/antiox9010024

42. Kumari A, Yadav SK, Pakade YB, Singh B, Yadav SC (2010) Development of biodegradable nanoparticles for delivery of quercetin. Colloids Surf B 80:184-192

43. Li Z, Jiang H, Xu C, Gu L (2014) A review: Using nanoparticles to enhance absorption and bioavailability of phenolic phytochemicals. Food Hydrocoll 1-12. doi:10.1016/j.foodhyd.2014.05.010 
44. Liu W, Yang Y, Zhang J, Gatlin DM, Ringo E, Zhou Z (2014) Effects of dietary microencapsulated sodium butyrate on growth, intestinal mucosal morphology, immune response and adhesive bacteria in juvenile common carp (Cyprinus carpio) pre-fed with or without oxidised oil. Br J Nutr 112:15-29. doi:10.1017/S0007114514000610

45. Lowry OH, Rosebrough NJ, Farr AL, Randall RJ (1951) Protein measurement with the Folin phenol reagent. J Biol Chem 193(1):265-275

46. Luliski P (2013) Molecular imprinted polymers as the future drug delivery devices. Acta Pol Pharm 70(4):601-609

47. Marklund S, Marklund G (1974) Involvement of superoxide anion radical in autoxidation of pyrogallol and a convenient assay of superoxide dismutase. Eur j biochem 46:469-474

48. Marshall BM, Levy SB (2011) Food animals and antimicrobials: Impacts on human health.Clinical Microbio. Rev 24:718-733

49. Martínez-Álvarez RM, Morales AE, Sanz A (2005) Antioxidant defenses in fish: Biotic and abiotic factors. Rev Fish Biol Fish 15:75-88

50. Maslowski KM, Mackay CR (2011) Diet, gut microbiota and immune responses. Nat Immunol 12:5-9

51. McClements DJ, Jafari SM (2018) Chapter 1 - General Aspects of nanoemulsions and their formulation. Nanoemulsions. Formulation, Applications, and Characterization. 3-20. doi: 10.1016/B978-0-12-811838-2.00001-1

52. Metón I, Salgado MC, Anemaet IG, González JD, Fernández F, Baanante IV (2015) Alanine aminotransferase: A target to improve utilisation of dietary nutrients in aquaculture.Int. j. recent adv.133-148

53. Morken T, Kraugerud OF, Barrows FT, Sørensen M, Storebakken T, Øverland M (2011) Sodium diformate and extrusion temperature affect nutrient digestibility and physical quality of diets with fish meal and barley protein concentrate for rainbow trout (Oncorhynchus mykiss). Aquaculture 317:138-148

54. Nie L, Zhou QJ, Qiao Y, Chen J (2017) Interplay between the gut microbiota and immune responses of ayu (plecoglossus altivelis) during vibrio anguillarum infection. Fish Shellfish Immunol 68:479487

55. Nigam AK, Kumari U, Mittal AK (2012) Comparative analysis of innate immune parameters of the skin mucous secretions from certain freshwater teleosts, inhabiting different ecological niches. Fish Physiol Biochem 38:1245-1256

56. Ng WK, Koh CB (2016) The utilization and mode of action of organic acids in the feeds of cultured aquatic animals. Rev Aquac 0:1-27

57. Omosowone OO, Dada AA, Adeparusi EO (2018) Comparison of dietary butyric acid supplementation effect on growth performance and body composition of Clarias gariepinus and Oreochromis niloticus fingerlings. Iran J Fish Sci 17(2):403-412. doi: 10.22092/IJFS.2018.115901

58. Opiyo MA, Marijani E, Muendo P, Odede R, Leschen W, Charo-Karisa HA (2018) Review of aquaculture production and health management practices of farmed fish in Kenya. Int J Vet Sci Med 6:141-148 
59. Palaksha KJ, Shin GW, Kim YR, Jung TS (2008) Evaluation of non-specific immune components from the skin mucus of olive flounder (Paralichthys olivaceus). Fish Shellfish Immunol 24(4):479488

60. Paramera El, Konteles SJ, Karathanos VT (2011) Stability and release properties of curcumin encapsulated in Saccharomyces cerevisiae, -cyclodextrin and modified starch. Food Chem 125:913922

61. Park JH, Lee S, Kim JH, Park K, Kim K, Kwon IC (2008) Polymeric nanomedicine for cancer therapy. Prog Polym Sci 33(1):113-137

62. Partenen KH, Mroz Z (1999) Organic acids for performance enhancement in pig diets. Nutr Res Rev $12: 1-30$

63. Piletsky S, Turner A (2006) A new generation of chemical sensors based on mips. In: Piletsky SA, Turner APF (eds) Molecular Imprinting of Polymers. Landes Bioscience, Georgetown, TX, USA, pp 64-79

64. Piva A, Pizzamiglio V, Mauro M, Tedeshchi M, Piva G (2007) Lipid microencapsulation allows slow release of organic acids and natural identical flavors along the swine intestine. Anim Sci 85:486-493

65. Poncelet D (2006) Microencapsulation: fundamentals, methods and applications. Surf Chem Biomed Environ Sci 228:23-34

66. Puoci F, Cirillo G, Curcio M, Parisi Ol, lemma F, Picci N (2011) Molecularly imprinted polymers in drug delivery: state of art and future perspectives. Expert Opin Drug Deliv 8(10):1379-1393

67. Qian M, Cai D, Verhey K, Tsai B (2009) A lipid receptor sorts polyomavirus from the endolysosome to the endoplasmic reticulum to cause infection.PLoS Pathog. 5 (6), e1000465

68. Raja K, Aanand P, Padmavathy S, Sampathkumar JS (2019) Present and future market trends of Indian ornamental fish sector. Int j fish aquat sci 7(2):06-15

69. Ram RN, Sathyanesan AG (1985) Mercuric chloride, cythion and ammonium sulfate induced changes in the brain, liver and ovarian alkaline phosphatase content in the fish Channa punctatus. Envir Ecol 3(2):263-268

70. Rastiannasab A, Afsharmanesh S, Rahimi R, Sharifian I (2016) Alternations in the liver enzymatic activity of Common carp, Cyprinus carpio in response to parasites, Dactylogyrus spp. and Gyrodactylus spp. J Parasit Dis. 40 (4), 1146-1149. doi: 10.1007/s12639-014-0638-9

71. Reitman S, Frankel S (1957) A colorimetric method for the determination of serum glutamic oxalacetic and glutamic pyruvic transaminases. Am J Clin Pathol 28(1):56-63

72. Rico A, Satapornvanit K, Haque MM, Min J, Nguyen PT, Telfer TC, van den Brink PJ (2012) Use of chemicals and biological products in Asian aquaculture and their potential environmental risks: a critical review. Rev Aquac 4:75-93. doi:10.1111/j.1753-5131.2012.01062.x

73. des Rieux A, Fievez V, Garinot M, Schneider Y-J, Preat V (2006) Nanoparticles s potential oral delivery systems of proteins and vaccines: a mechanistic approach. J Control Release 116(1):1-27 
74. Romano N, Koh CB, Ng WK (2014) Dietary microencapsulated organic acids blend enhances growth, phosphorus utilization, immune response, hepatopancreatic integrity and resistance against Vibrio harveyi in white shrimp, Litopenaeus vannamei, Aquaculture.. doi:

10.1016/j.aquaculture.2014.09.037

75. Rombout JHWM, Abelli L, Picchietti S, Scapigliati G, Kiron V (2011) Teleost intestinal immunology. Fish Shellfish Immunol 31(5):616-626

76. Safari O, Paolucci M (2018) Effect of in vitro selected synbiotics (galactooligosaccharide and mannanoligosaccharide with or without Enterococcus faecalis) on growth performance, immune responses and intestinal microbiota of juvenile narrow clawed crayfish, Astacus leptodactylus leptodactylus Eschscholtz, 1823. Aquac Nutr 24:247-259

77. Safari R, Kavandi SH, M (2016) Modulation of antioxidant defence and immune response in zebra fish (Danio rerio) using dietary sodium propionate. Fish Physiol Biochem 42:1733-1739

78. Safari R, Nejadmoghadam SH, Khalili S, M (2017) Non-specific immune parameters, immune, antioxidant and growth-related genes expression of common carp (Cyprinus carpio L.) fed sodium propionate. Aquac Res 1-9. doi:10.1111/are.13272

79. Safari O, Paolucci M, Motlagh HM (2021) Effect of dietary encapsulated organic salts (Na-acetate, Na-butyrate, Na-lactate and Na-propionate) on growth performance, haemolymph, antioxidant and digestive enzyme activities and gut microbiota of juvenile narrow clawed crayfish. Astacus leptodactylus Eschscholtz, 1823 Aquac Nutr 27:91-104

80. Safari 0, Sarkheil M (2018) Dietary administration of eryngii mushroom (Pleurotus eryngii) powder on haemato-immunological responses, bactericidal activity of skin mucus and growth performance of koi carp fingerlings (Cyprinus carpio koi). Fish Shellfish Immunol 80:505-513

81. Sajeevan T, Philip R, Singh IB (2009) Dose/frequency: a critical factor in the administration of glucan as immunostimulant to Indian white shrimp Fenneropenaeus indicus. Aquaculture 287(3):248-252. doi:10.1016/j.aquaculture.2008.10.045

82. Sarkheil M, Kordestani D, Safari O (2021) Dietary supplementation with powder and gelatine micro and nanoencapsulated sodium propionate: Influence on growth performance, digestive and antioxidant enzymes and mucosal immunity of koi carp (Cyprinus carpio koi). Aquac Nutr 00:1-16. doi: 10.1111/anu. 13360

83. Senapati S, Mahanta AK, Kumar S, Maiti P (2018) Controlled drug delivery vehicles for cancer treatment and their performance. Signal Transduct Target Ther 3:7. doi:10.1038/s41392-017-0004-3

84. Silva BC, Vieira FN, Mouri no JLP, Bolivar N, Seiffert WQ (2016) Butyrate and propionate improve the growth performance of Litopenaeus vannamei. Aquac Res 47:612-623

85. Siwicki AK, Anderson DP, Rumsey GL (1994) Dietary intake of immunostimulants by rainbow trout affects non-specific immunity and protection against furunculosis. Veterinary Immunology and Immunopathology 41:125-139. doi:10.1016/0165-2427(94)90062-0

86. Sotoudeh E, Sangari M, Bagheri D, Morammazi S, Torfi Mozanzadeh M (2020) Dietary organic acid salts mitigate plant protein induced inflammatory response and improve humoral immunity, 
antioxidative status and digestive enzyme activities in yellowfin seabream, Acanthopagrus latus. Aquac Nutr 00:1-12

87. Su X, Li X, Leng X, Tan C, Liu B, Chai X (2014) The improvement of growth, digestive enzyme activity and disease resistance of white shrimp by the dietary citric acid. Aquac Int 22:1823-1835

88. Subramanian S, MacKinnon SL, Ross NW (2007) A comparative study on innate immune parameters in the epidermal mucus of various fish species. Comp Biochem Physiol B, Biochem Molecular Biology 148(3):256-263. doi:10.1016/j.cbpb.2007.06.003

89. Tian L, Zhou XQ, Jiang WD, Liu Y, Wu P, Jiang J, Kuang SY, Tang L, Tang WN, Zhang YA, Xie F, Feng L (2017) Sodium butyrate improved intestinal immune function associated with NF-kB and p38MAPK signalling pathways in young grass carp (Ctenopharyngodon idella). Fish Shellfish Immunol 66:548-563

90. Topping DL, Clifton PM (2001) Short-chain fatty acids and human colonic function: roles of resistant starch and nonstarch polysaccharides. Physiol Rev 81:1031-1064

91. Trenzado C, Hidalgo MC, García-Gallego M, Morales AE, Furné M, Domezain A, Domezain J, Sanz A (2006) Antioxidant enzymes and lipid peroxidation in sturgeon Acipenser naccarii and trout Oncorhynchus mykiss. A comparative study. Aquaculture 254:758-767

92. Van der Wielen $P$ (2002). In: In: Blok MC, Vahl HA, De Lange L, Van De Braak AE, Hemke G et al (eds) Dietary strategies to influence the gastrointestinal microflora of young animals and its potential to improve intestinal health. Nutrition and Health of the Gastrointestinal Tract. Wageningen Academic Publishers, Wageningen, the Netherlands, pp 37-60

93. Van Doan H, Ring $\varnothing$ SH, Esteban E, Dadar MA, Dawood M, Faggio MAO, C (2020) Host-associated probiotics: a key factor in sustainable aquaculture. Rev Fish Sci Aquac 28(1):16-42. doi:10.1080/23308249.2019.1643288

94. Wassef EA, Saleh NE, Abdel-Meguid NE, Barakat KM, Abdel-Mohsen HH, El-bermawy NM (2019) Sodium propionate as a dietary acidifier for European seabass (Dicentrarchus labrax) fry: immune competence, gut microbiome, and intestinal histology benefits. Aquac Int 1-17. doi: 10.1007/s10499-019-00446-7

95. Wongsasak U, Chaijamrus S, Kumkhong S, Boonanuntanasarn S (2014) Effects of dietary supplementation with b-glucan and synbiotics on immune gene expression and immune parameters under ammonia stress in Pacific white shrimp. Aquaculture 436:179-187

96. Worthington C (1991) Worthington enzyme manual related biochemical, Freehold, New Jersey

97. Wuertz S, Schroeder A, Wanka KM (2021) Probiotics in Fish Nutrition-Long-Standing Household Remedy or Native Nutraceuticals? Water 13:1348. doi:10.3390/w13101348

98. Yano T (1992) Assays of hemolytic complement activity. Techniques in Fish Immunology.131-141

99. Zaidi SB (2016) Molecular imprinted polymers as drug delivery vehicles. Drug Deliv 23(7):22622271. doi: $10.3109 / 10717544.2014 .970297$

100. Zhou Z, Ding Z, Huiyuan L (2007) Effects of dietary short-chain fructooligosaccharides on intestinal microflora, survival, and growth performance of juvenile white shrimp, Litopenaeus vannamei. J 
World Aquac Soc 38(2):296-301. doi:10.1111/j.1749-7345.2007.00099.x

101. Zhu Y, Yang L, Huang D, Zhu Q (2017) Molecularly imprinted nanoparticles and their releasing properties, bio-distribution as drug carriers. Asian J Pharm Sci 12:172-178

102. Zikic RV, Stajn S, Pavlovic Z, Ognjanovic BI, Saicic S (2001) Activities of superoxide dismutase and catalase in erythrocyte and plasma transaminases of goldfish (Carassius auratus gibelio Bloch.) exposed to cadmium. Physiol Res 50:105-111

\section{Tables}

Table 1. Ingredients and proximate composition of experimental diets 


\begin{tabular}{|c|c|c|c|c|c|}
\hline Ingredients (g kg-1 dry-weight basis) & & Control & $\begin{array}{l}\text { MIP } \\
\text { NPs }\end{array}$ & P-SP & $\begin{array}{l}\text { MIP-SP } \\
\text { NPs }\end{array}$ \\
\hline Fish meal ${ }^{1}$ & & 205 & 205 & 205 & 205 \\
\hline Wheat flour ${ }^{1}$ & & 220 & 220 & 220 & 220 \\
\hline Soybean meal ${ }^{1}$ & & 250 & 250 & 250 & 250 \\
\hline Corn gluten ${ }^{1}$ & & 125 & 125 & 125 & 125 \\
\hline Soybean oil ${ }^{1}$ & & 25 & 25 & 25 & 25 \\
\hline Fish oil ${ }^{1}$ & & 25 & 25 & 25 & 25 \\
\hline Mineral premix ${ }^{2}$ & & 35 & 35 & 35 & 35 \\
\hline Vitamin premix ${ }^{3}$ & & 35 & 35 & 35 & 35 \\
\hline Carboxymethyl cellulose ${ }^{4}$ & & 59 & 5.18 & 54 & 0.18 \\
\hline Anti-fungi ${ }^{5}$ & & 15 & 15 & 15 & 15 \\
\hline $\mathrm{BHT}^{6}$ & & 1 & 1 & 1 & 1 \\
\hline Vit $C^{7}$ & & 5 & 5 & 5 & 5 \\
\hline Sodium propionate ${ }^{8}$ & & 0 & 0 & 5 & 0 \\
\hline Molecular imprinting polymer nanoparticles & & 0 & 53.82 & 0 & 0 \\
\hline $\begin{array}{l}\text { Molecular imprinting polymer-sodium propionate } \\
\text { nanoparticles }\end{array}$ & & 0 & 0 & 0 & 58.82 \\
\hline \multicolumn{6}{|l|}{ Proximate composition ( $\mathrm{g} \mathrm{kg}^{-1}$ dry-weight basis) } \\
\hline Dry matter & 958.6 & & 958.6 & 958.6 & 958.6 \\
\hline Crude protein & 405 & & 405 & 405 & 405 \\
\hline Crude fat & 62 & & 62 & 62 & 62 \\
\hline Crude fiber & 341 & & 341 & 341 & 341 \\
\hline Ash & 71 & & 71 & 71 & 71 \\
\hline Cross energy $(\mathrm{Mj} / \mathrm{Kg})$ & 16.15 & & 16.15 & 16.15 & 16.15 \\
\hline $\mathrm{pH}$ & 5.91 & & 5.87 & 5.79 & 5.77 \\
\hline
\end{tabular}


MIP-NPs: molecular imprinted polymer nanoparticles; P-SP: powder sodium propionate; MIP-SP NPs: molecular imprinted polymer-sodium propionate nanoparticles.

${ }^{1}$ Behparvar Aquafeed Co, Iran.

${ }^{2}$ Mineral premix contains ( $\mathrm{mg} \mathrm{kg}^{-1}$ ): Mg, 100; Zn, 60; Fe, 40; Cu, 5; Co, 0.1 and I, 1 (Kimia Roshd Co, Gorgan, Iran).

${ }^{3}$ Vitamin premix contains $\left(\mathrm{mg} \mathrm{kg}^{-1}\right)$ : $\mathrm{E}, 30 ; \mathrm{K}, 3$; thiamine, 2; riboflavin, 7; pyridoxine, 3; pantothenic acid, 18; niacin, 40; folacin, 1.5; choline, 600; biotin, 0.7 and cyanocobalamin, 0.02 (Kimia Roshd Co, Gorgan, Iran).

${ }^{4}$ Sigma-Aldrich Co, Germany.

${ }^{5}$ Kimia Roshd Co, Gorgan, Iran.

${ }^{6}$ Kimia Roshd Co, Gorgan, Iran.

${ }^{7}$ Kimia Roshd Co, Gorgan, Iran.

${ }^{8}$ Sigma-Aldrich Co, Germany.

Table 2. Growth performance, feed utilization indices and survival rate of African cichlid (L. lividus) fingerlings fed on diets supplemented with different forms of sodium propionate for 56 days (mean \pm SD, $n=3)$. 


\begin{tabular}{|c|c|c|c|c|}
\hline \multirow[b]{2}{*}{ Parameters } & \multicolumn{4}{|c|}{ Dietary sodium propionate groups } \\
\hline & Control & MIP NPs & P-SP & MIP-SP NPs \\
\hline Initial weight (g) & $0.51 \pm 0.017^{a}$ & $0.50 \pm 0.006^{a}$ & $0.50 \pm 0.002^{\mathrm{a}}$ & $0.50 \pm 0.009^{\circ}$ \\
\hline Final weight (g) & $5.12 \pm 0.32^{\mathrm{a}}$ & $5.24 \pm 0.09^{a}$ & $6.11 \pm 0.17^{b}$ & $6.83 \pm 0.64^{c}$ \\
\hline Weight gain (g) & $4.60 \pm 0.33^{a}$ & $4.73 \pm 0.08^{\mathrm{a}}$ & $5.61 \pm 0.17^{b}$ & $6.33 \pm 0.65^{c}$ \\
\hline $\begin{array}{l}\text { SGR } \\
\text { (\%BW day-1( }\end{array}$ & $4.11 \pm 0.15^{\mathrm{a}}$ & $4.16 \pm 0.009^{a}$ & $4.45 \pm 0.05^{b}$ & $4.64 \pm 0.19^{b}$ \\
\hline DGI (g) & $0.082 \pm 0.005^{a}$ & $0.084 \pm 0.001^{a}$ & $0.10 \pm 0.003^{b}$ & $0.12 \pm 0.010^{c}$ \\
\hline $\mathrm{CF}\left(\mathrm{g} \mathrm{cm}^{-3}\right)$ & $1.56 \pm 0.14^{\mathrm{a}}$ & $1.57 \pm 0.13^{\mathrm{a}}$ & $1.83 \pm 0.12^{\mathrm{a}}$ & $1.87 \pm 0.19^{a}$ \\
\hline FCR & $2.18 \pm 0.043^{c}$ & $2.19 \pm 0.09^{c}$ & $1.80 \pm 0.12^{b}$ & $1.52 \pm 0.166^{\circ}$ \\
\hline Survival rate (\%) & $82.22 \pm 5.55^{\mathrm{a}}$ & $84.07 \pm 8.48^{a}$ & $85.92 \pm 8.48^{a}$ & $93.33 \pm 5.55^{\circ}$ \\
\hline
\end{tabular}

MIP-NPs: molecular imprinted polymer nanoparticles; P-SP: powder sodium propionate; MIP-SP NPs: molecular imprinted polymer-sodium propionate nanoparticles. SGR: specific growth rate; DGI: daily growth index; CF: condition factor; FCR: food conversion ratio. Data assigned with different letters in a row are significantly different (ANOVA, $P<0.05$ ).

Table 3. Digestive enzymes activity (U mg protein ${ }^{-1} \mathrm{~min}^{-1}$ ) of African cichlid (L. lividus) fed on diets supplemented with different forms of sodium propionate for 56 days (mean $\pm S D, n=3$ ). 


\begin{tabular}{|lllll|}
\hline & \multicolumn{4}{c|}{ Dietary sodium propionate groups } \\
\cline { 2 - 5 } Enzyme & Control & MIP NPs & P-SP & MIP-SP NPs \\
\hline Protease & $1.50 \pm 0.065^{\mathrm{a}}$ & $1.52 \pm 0.015^{\mathrm{a}}$ & $1.79 \pm 0.020^{\mathrm{b}}$ & $1.94 \pm 0.01^{\mathrm{c}}$ \\
\hline Trypsin & $1.22 \pm 0.086^{\mathrm{a}}$ & $1.25 \pm 0.049^{\mathrm{a}}$ & $1.47 \pm 0.020^{\mathrm{b}}$ & $1.56 \pm 0.021^{\mathrm{b}}$ \\
\hline Lipase & $1.27 \pm 0.045^{\mathrm{a}}$ & $1.28 \pm 0.070^{\mathrm{a}}$ & $1.47 \pm 0.045^{\mathrm{b}}$ & $1.89 \pm 0.025^{\mathrm{c}}$ \\
\hline amylase & $0.55 \pm 0.015^{\mathrm{a}}$ & $0.56 \pm 0.25^{\mathrm{a}}$ & $0.57 \pm 0.30^{\mathrm{a}}$ & $0.58 \pm 0.20^{\mathrm{a}}$ \\
\hline Alkaline phosphatase & $0.93 \pm 0.060^{\mathrm{a}}$ & $0.90 \pm 0.035^{\mathrm{a}}$ & $1.26 \pm 0.065^{\mathrm{b}}$ & $1.41 \pm 0.17^{\mathrm{b}}$ \\
\hline
\end{tabular}

MIP-NPs: molecular imprinted polymer nanoparticles; P-SP: powder sodium propionate; MIP-SP NPs: molecular imprinted polymer-sodium propionate nanoparticles. Data assigned with different letters in a row are significantly different (ANOVA, $\mathrm{P}<0.05)$.

\section{Figures}
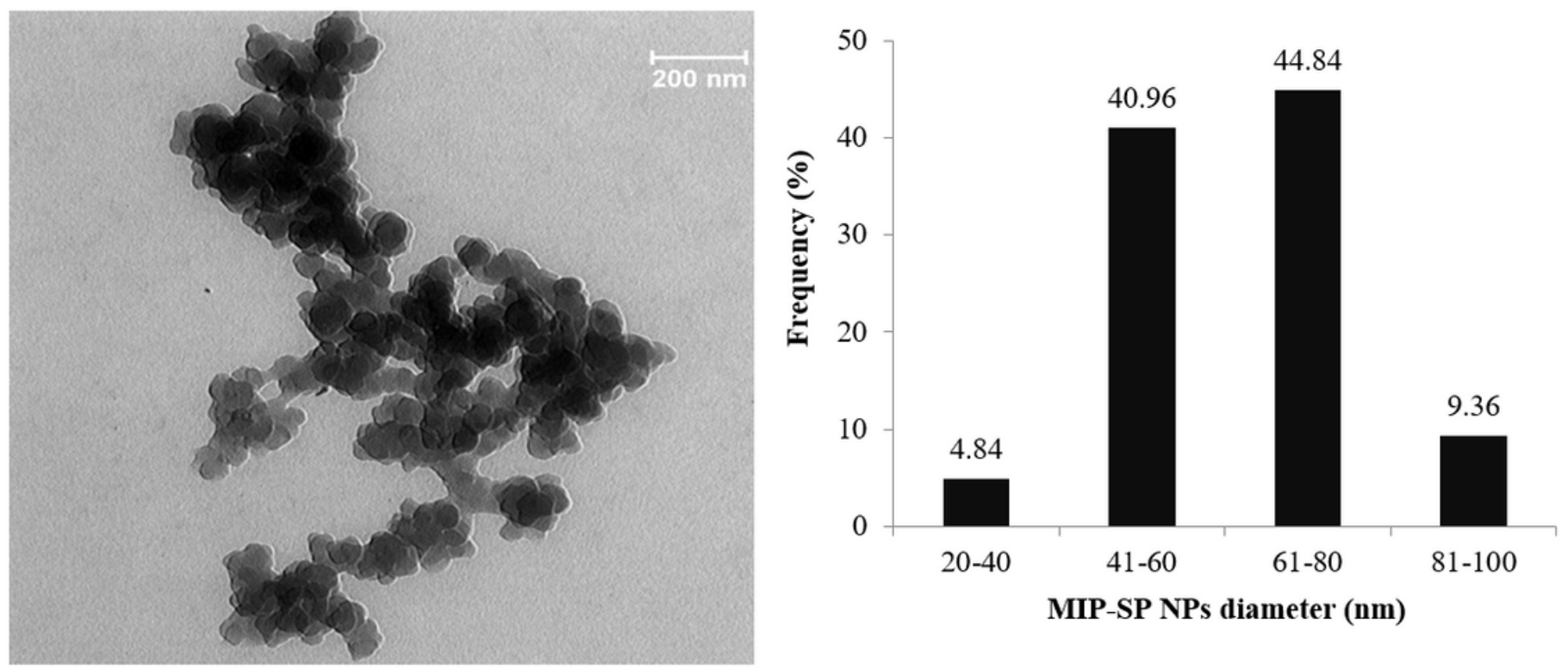
Figure 1

FE-SEM micrograph (a), EDS pattern (b), TEM micrograph (c) and histogram for particle size distribution of MIP-SP nanoparticles (d).

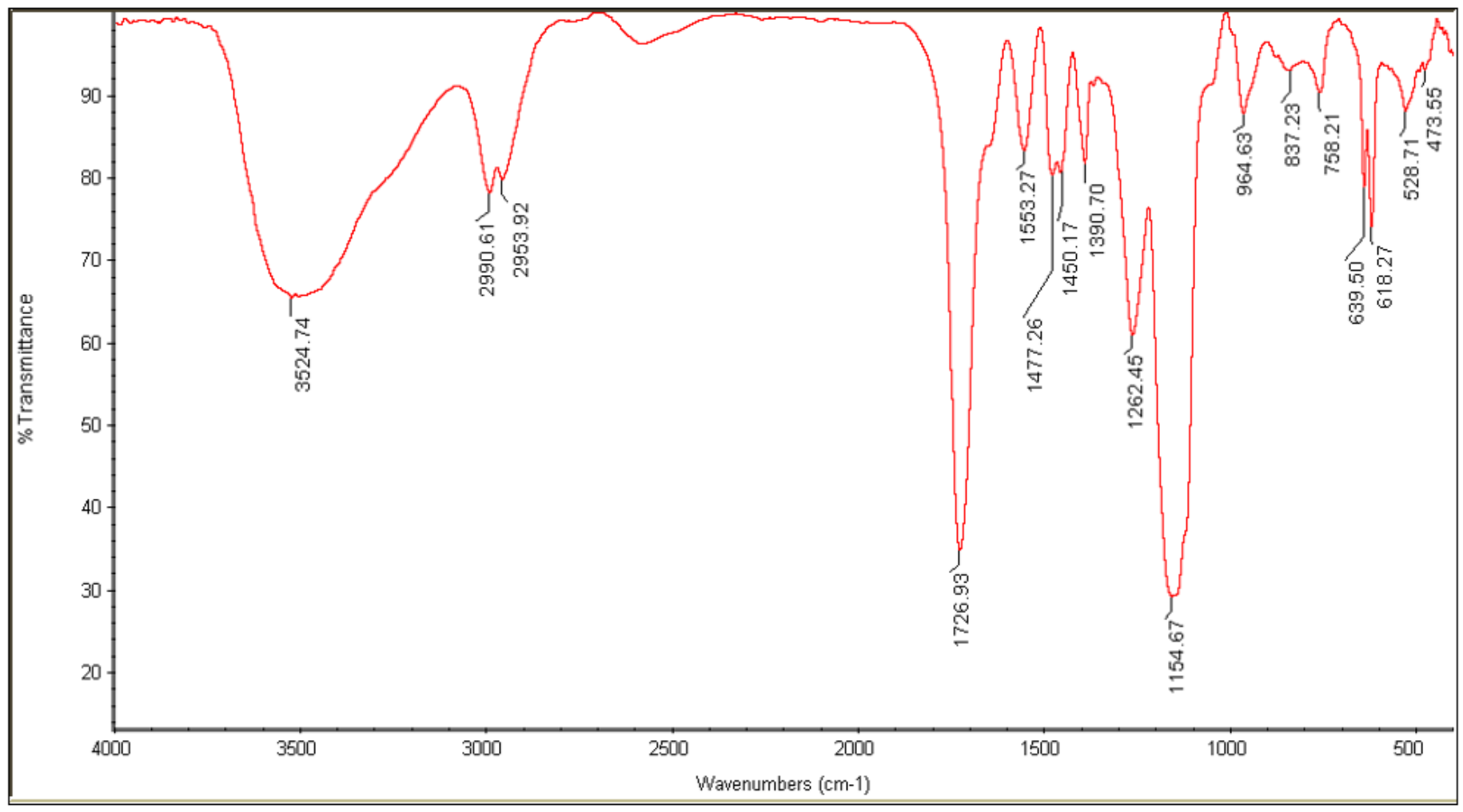

Figure 2

FT-IR spectra of MIP-SP NPs. 
(a)

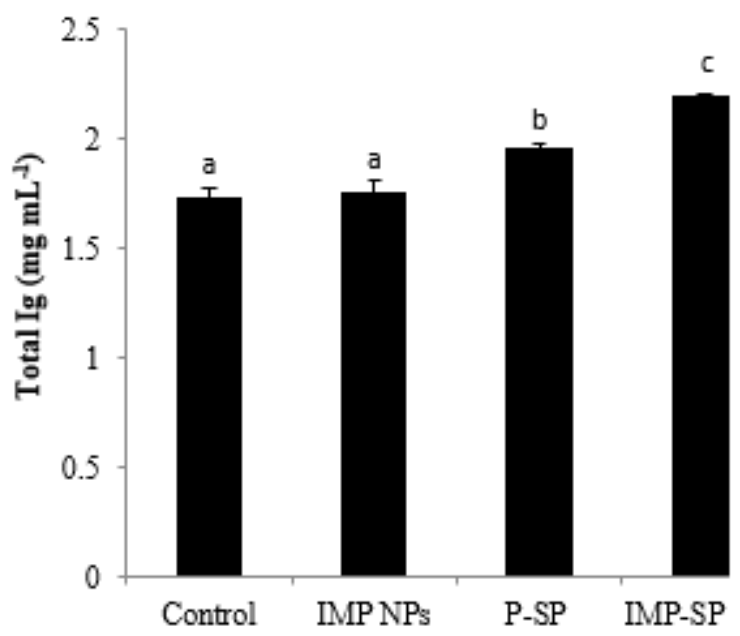

(b)

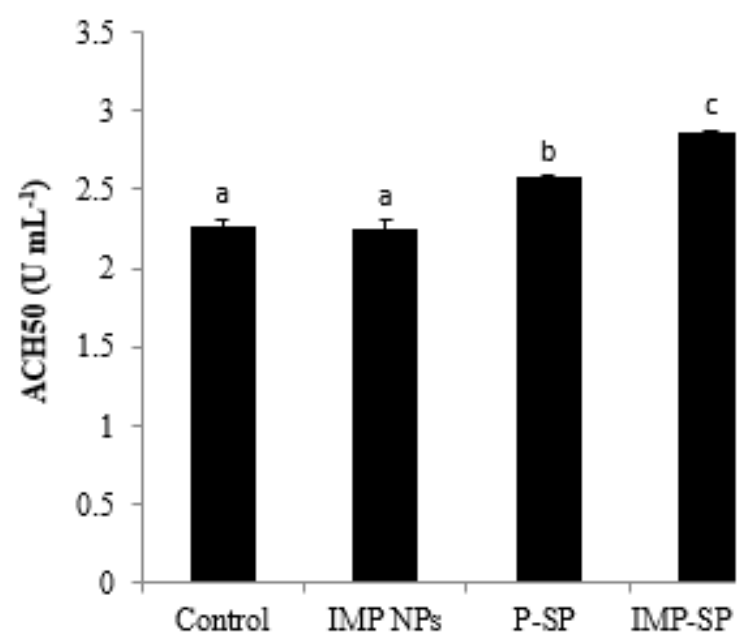

(c)

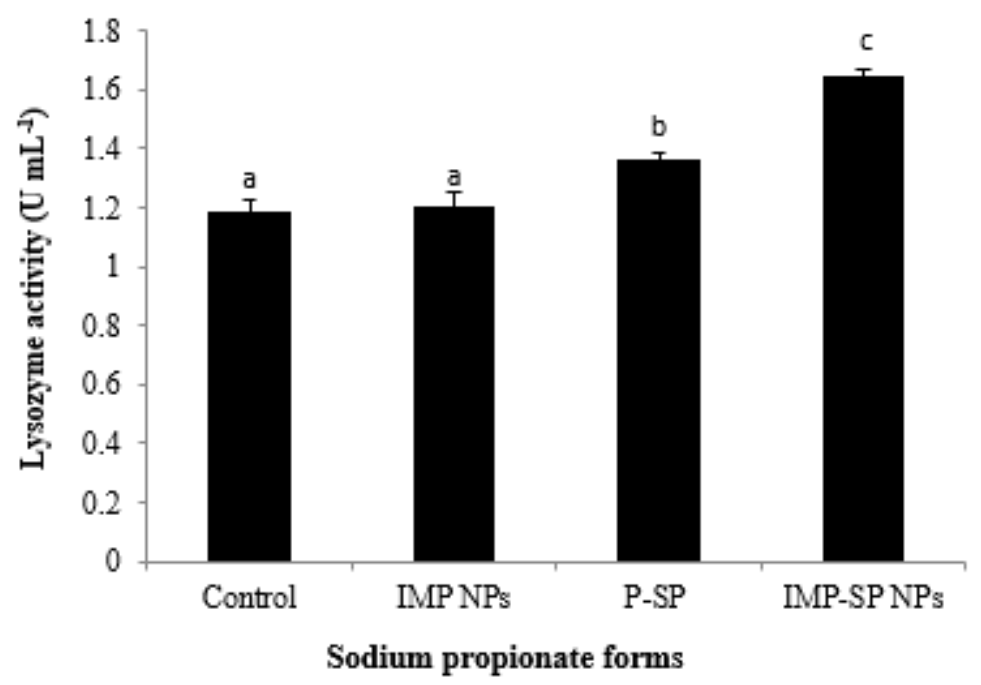

Figure 3

Total immunoglobulin (lg) (a), alternative haemolytic complement activity (ACH50) (b) and lysozyme activity (c) levels in skin mucus of African cichlid (L. lividus) fingerlings fed on diets supplemented with different forms of sodium propionate for 56 days. Bars assigned with different letters are significantly different (ANOVA, P 0.05 ). MIP-NPs: molecular imprinted polymer nanoparticles; P-SP: powder sodium propionate; MIP-SP NPs: molecular imprinted polymer-sodium propionate nanoparticles. 
(a)

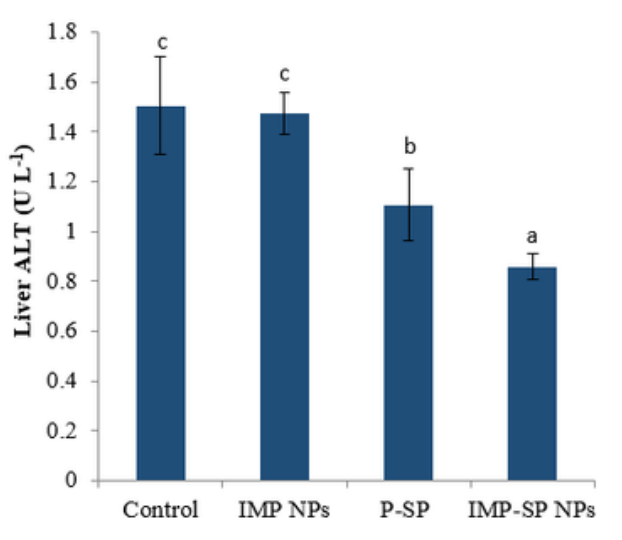

(c)

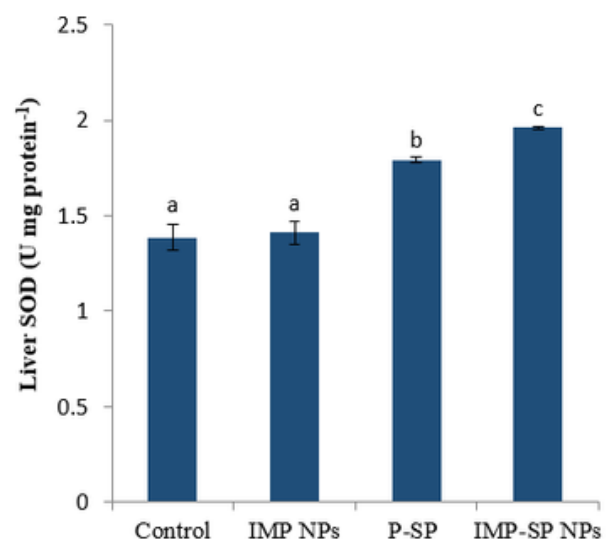

(b)

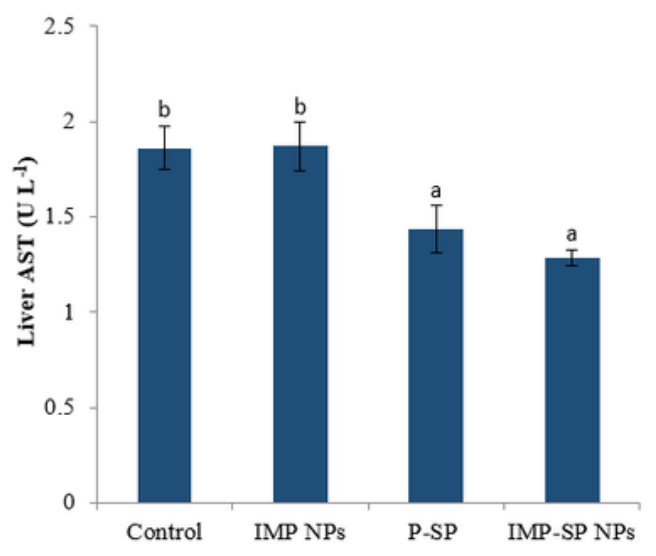

(d)

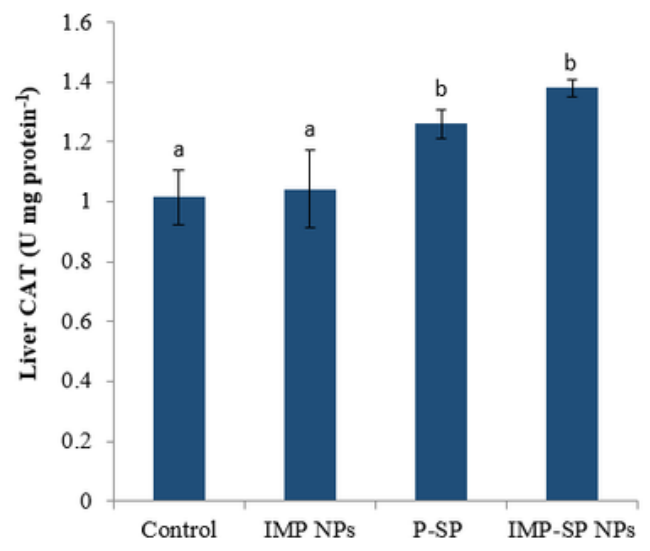

(e)

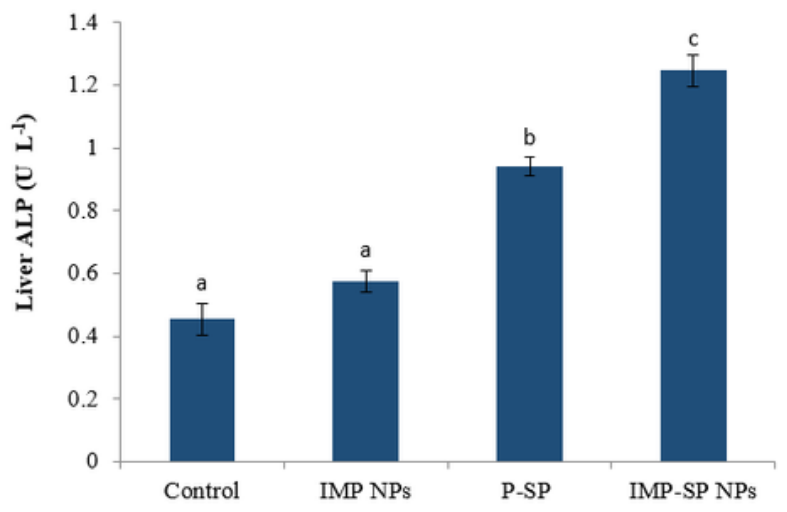

Figure 4

Alanine aminotransferase (ALT) (a), aspartate aminotransferase (AST) (b), superoxide dismutase (SOD) (c), catalase (CAT) (d), and alkaline phosphatase (ALP) (e) levels in liver of African cichlid (L. lividus) fingerlings fed on diets supplemented with different forms of sodium propionate for 56 days. Bars assigned with different letters are significantly different (ANOVA, $P<0.05)$. MIP-NPs: molecular imprinted 
polymer nanoparticles; P-SP: powder sodium propionate; MIP-SP NPS: molecular imprinted polymersodium propionate nanoparticles.

\section{Supplementary Files}

This is a list of supplementary files associated with this preprint. Click to download.

- Highlights.docx 